\title{
Grain Yield
}

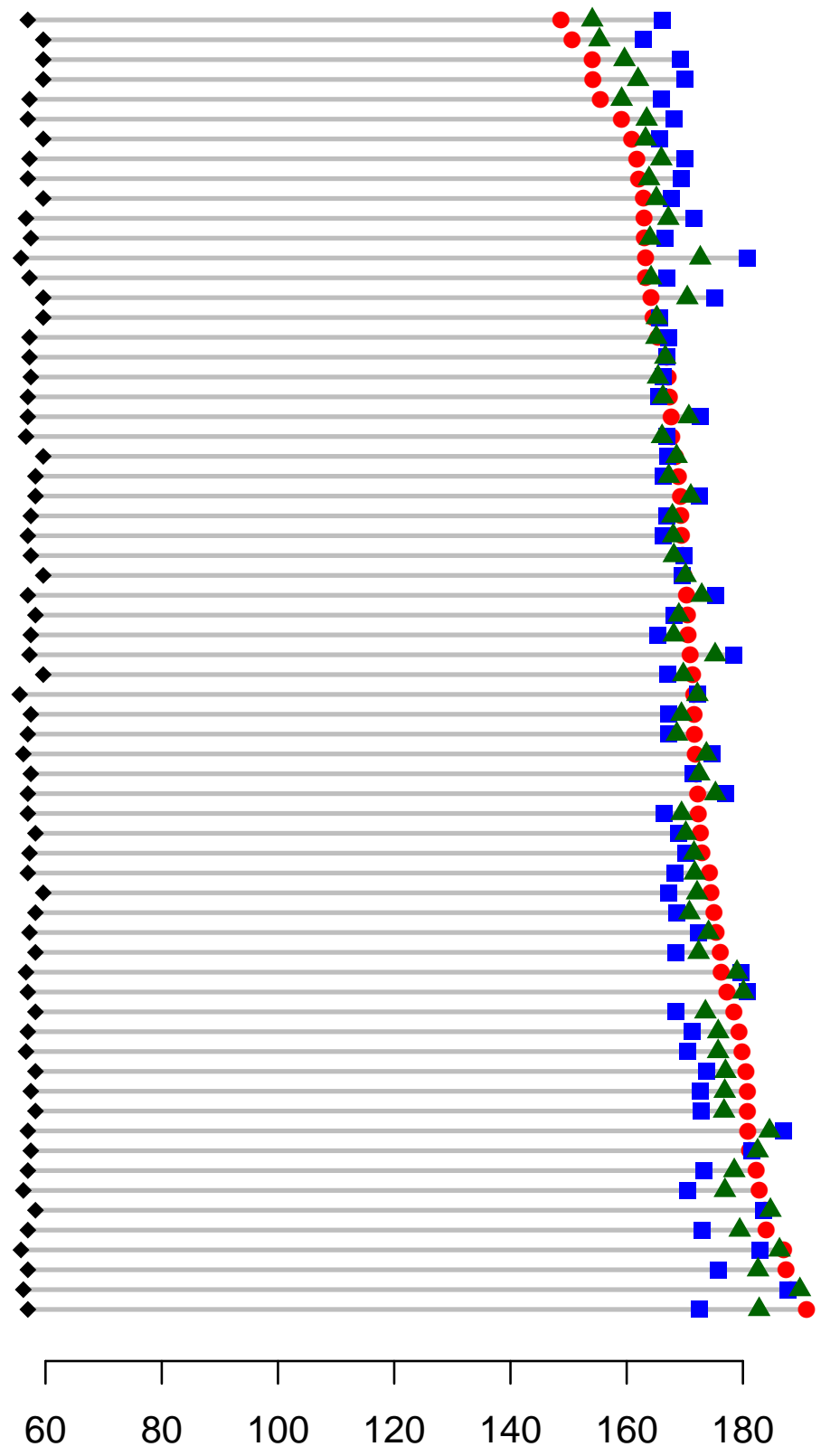

Breeding Value 